\title{
Passages to Peace
}

In 1757 , when the Duke of Mecklenburg-Schwerin, Friedrich II, allowed Swedish armies to pass through his territory, he incurred the wrath of the Prussian throne to which he owed fealty. As a consequence, the duke was forced to take refuge in the Hanseatic city of Lübeck.

The history of warfare knows countless parallels to this scenario. In most cases, the permission to pass through a country was coupled with provision by that country of alimentary succor for the army. From antiquity to modernity, food and water for troops and horses constituted a conventional obligation that both allies and vassals were expected to meet when a campaigning force traversed their country. ${ }^{\mathrm{I}}$

In his monumental and immensely influential I625 work De jure belli ac pacis (The Rights of War and Peace), Hugo Grotius devoted many pages to the passage of armies through the territories of third parties. Summoning a wide range of ancient and medieval sources, he began his disquisition with, and assigned great weight to, texts from the Pentateuch. The issues he addressed include the question of whether a campaigning army may be allowed to stay for an extended period in a foreign country or purchase provisions from its inhabitants. Grotius concluded that the right to cross neighboring lands must be granted if another route is not practicable. A commander should first formally request permission to pass through a neighboring

I The provisioning of troops is a standard vassal obligation or, more generally, an opportunity for a community to demonstrate loyalty, as can be seen not least from Josephus's Jewish War I.5, 8.I, 9.4, I3.8, 20.3, and passim. 
territory, but when it is not conferred, he may proceed, resorting to force if necessary. ${ }^{2}$

The deliberations of the Dutch jurist have directly informed subsequent discussions of rights of passage in international law, and the illustrations he provides from sundry times and places render it likely that the scribes responsible for the Pentateuchal texts he cites had ancient military conventions in mind, even if these scribes appear to have invented ad hoc a range of scenarios for their national narrative.

The texts in question purport to recount Israel's earliest encounters with its future neighbors. By constructing memories and countermemories of these encounters, the biblical scribes not only explained how Israel came to occupy various territories in the Transjordan; they also addressed issues presented by peoples on their borders. ${ }^{3}$

\section{PASSAGE DENIED}

The book of Numbers narrates Israel's long and eventful voyage through the wilderness that separates Egypt from the southern Levant. ${ }^{4}$ In an uninhabited wasteland they are left to themselves and their own internal issues. But in the final stages of their journey, as they draw near to the Promised Land, they come into contact, for the first time, with the

${ }^{2}$ Grotius refers to an episode recounted by Plutarch when the Athenian general Cimon, coming to the assistance of Sparta, led his troops through the lands of the Corinthians without giving them prior notice. The Corinthians reproved him: "When one desires to enter a house, it is usual to knock at the door and wait for admission!" (see Book Two, 2.22-24 and 3.I-I9). The issue of army passage is directly related, for navies, to the "rights to the seas" - Grotius himself wrote an important book on this issue, Mare Liberum (The Freedom of the Seas), published in I609 - and now, for air forces, to "flyover rights."

3 The biblical texts discussed here have had a direct impact on European notions of just war; for example, John Locke drew directly on them when developing the ideas in his Second Treatise of Government (I689). At the most basic level, the biblical accounts present an alternative to the campaigns conducted by the imperial powers of their day. Instead of seizing all the territories that lay in their path, the Israelites strove to skirt the borders of their future neighbors and went to great lengths to avoid conflict with their neighbors. As a band of refugees, they were making their way to their homeland, and their intention was to occupy solely their divinely appointed borders. For help in thinking about the implications of our findings in Part I for political theology, see John Haskell, Political Theology and International Law (Leiden: Brill, 2018).

${ }^{4}$ On compositional issues related to the episodes from Numbers (and their literary pendants in Deuteronomy), see Stephen Germany, The Exodus-Conquest Narrative: The Composition of the Non-Priestly Narratives in Exodus-Joshua (Tübingen: Mohr Siebeck, 20I7). 
kingdoms that occupy the regions surrounding their homeland, and these confrontations with outsiders present unprecedented problems.

The first civilization they face is the southernmost kingdom of Edom, whose inhabitants are identified as the descendants of Esau, the twin brother of Israel's ancestor, Jacob. Straightaway, Moses sends messengers to their king with the following petition:

Thus says your brother Israel: "You know all the troubles that we've suffered. Our ancestors went down to Egypt, where we lived a long time. The Egyptians oppressed us and our ancestors. When we cried to Yhwh, he heard our voice, and sent an angel and brought us out of Egypt. We reside now in Kadesh, a town on the edge of your borders. Let us please pass through your territory. We will not traverse field or vineyard, nor will we drink water from any well. We will go along the King's Highway, not veering to the right hand or to the left, until we exit your borders." Num. 20:14-I7

Notice that the subject of the petition is not Moses but "your brother Israel." By removing himself from the picture and recalling his people's sojourn and suffering in Egypt, Moses, as the fictive author of the petition, showcases his diplomatic savvy and rhetorical skills: the Edomites should understand that the supplicant is not an army on its way to conquer new territories but rather their own kin returning as refugees to their homeland after years of affliction in a foreign land.

Although the Israelites are the Edomites' own flesh and blood, they do not so much as ask for a drop of water from the Edomites' wells or a handful of grain from their fields. Even so, this kingdom denies them passage and threatens to take up arms against them. Giving their kin yet another chance to demonstrate compassion, the Israelite messengers insist that their people would keep to the beaten pathway and pay for any water that they or their livestock would drink. "We ask only for passage on foot - it is but a small matter" (Num. 20:19). Their repeated appeal fails to arouse pity, however, and the Edomites now march out with a host of heavily armed troops. "Thus Edom refused to grant Israel passage through their territory, and Israel turned the other way" (Num. 20:2I).

In the next encounter with a foreign people, the Israelites do not have the chance to ask for permit of passage. The king of Arad (a city on Judah's southern frontier) hears about their arrival and immediately attacks them. Before retaliating, the Israelites make a pact with Yhwh that they will not take possession of Canaanite towns in the region if he grants them victory:

5 Unless otherwise stated, all translations are my own. 
When the Canaanite, the king of Arad, who lived in the Negeb, heard that Israel was coming by the way of Atharim, he fought against Israel and took some of them captive. Then Israel made a vow to Yhwh and said, "If you will indeed give this people into my hand, then I will utterly destroy their towns." Yhwh listened to the voice of Israel and handed over the Canaanites. They utterly destroyed them and their towns, so the place was called Hormah [a wordplay on "utterly destroyed"]. Num. 2I:I-3 ${ }^{6}$

This episode resembles the way in which the Amalekites, without prior provocation, attack the Israelites soon after they leave Egypt (Exod. I 7:8-I6). ${ }^{7}$ The difference is that the Amalekites are identified as landless marauders, so that when Israel retaliates, there are no cities to be destroyed, as in the war with Arad, or territory to be conquered, as in the impending conflicts with Sihon and Og. Nevertheless, the commemorative purpose of all the accounts we discuss here is made most explicit in the Amalekite episode, which concludes with Yhwh commanding Moses to "write this as a memorial in a scroll" and with Moses building an altar as a monument to the perpetual war between Yhwh and his enemy. Later, in the book of Deuteronomy, Moses reminds the nation of the Amalekites' aggression, commanding future generations to "erase the memory of Amalek from under heaven; do not forget!" (Deut. 25:I7-I9). ${ }^{8}$

After the war with Arad, the Israelites voyage onward until they arrive at the Amorite kingdom of Sihon. Before stepping foot in his territory, they request permission to traverse his borders:

Then Israel sent messengers to King Sihon of the Amorites, saying, "Let me please pass through your land. We will not turn aside into field or vineyard, nor will we drink water of any well. We will stick to the King's Highway until we have exited your borders." Num. 2I:2I-22

${ }^{6}$ This episode in 2I:I-3 appears to have been interpolated. (The same can be said of the account of Aaron's death and investiture of his son Eleazar in 20:23-29.) Notice how the reference to Israel's arrival at Mount Hor in 20:22 continues with the statement that they circumvented the land of Edom in 2I:4. (For texts connected with this one, see Num. I4:45; Josh. I2:I4; Judg. I:I7.) The pact between Israel and Yhwh in 2I:I-3 is part of a larger dispute about when and where the wars of conquest commenced (see the discussion in Part II). A helpful historical survey of this region is provided in Ido Koch and Lidar Sapir-Hen, "Beersheba-Arad Valley During the Assyrian Period," Semitica, 60 (20I8), 427-452.

7 Although the Amalek episode differs from the other texts treated in this section, its authors may have intended it to serve as the lens through which these texts are to be read.

${ }^{8}$ On the remarkable formulation "erase the memory of Amalek from under heaven; do not forget!" and the dynamics of memory-making in the Amalek texts, see Alana M. Vincent, Making Memory: Jewish and Christian Explorations in Monument, Narrative, and Liturgy (Cambridge: James Clarke, 20I4). 
This petition is similar to the one they had conveyed to the king of Edom. (The chief difference is that Moses is missing from this account, as in the preceding episode with the king of Arad. ${ }^{9}$ ) Once again, the enemy ruler refuses to grant permission, and he mobilizes "all his people to engage Israel in battle in the wilderness." As in the case of Arad, his assault is unsuccessful, yet this time the Israelites take possession of his country. The narrator makes it clear that when the Israelites seized land from the Amorites, they did not encroach on Ammonite territory:

Sihon came to Jahaz and fought against Israel. But Israel put them to the sword and took possession of their land - from the Arnon to the Jabbok, as far as the Ammonites, for Az marked the boundary of the Ammonites. Israel took all those towns. Israel settled in all the towns of the Amorites, in Heshbon, and in all its dependencies. Num. 21:23b-25 ${ }^{\text {10 }}$

As the Israelites venture northwards, they approach the territory of Bashan, and when its king attacks them, he meets the same fate as Sihon:

Then they turned and went up the road to Bashan. There King Og of Bashan came out against them, he and all his people, to do battle at Edrei. But Yhwh said to Moses, "Do not be afraid of him, for I have given him into your hand, with all his people, and all his land. You shall do to him as you did to King Sihon of the Amorites, who ruled in Heshbon." So they killed him, his sons, and all his people, until there was no survivor left; and they took possession of his land. Num. 21:33-35 ${ }^{\mathrm{II}}$

Finally, the nation arrives in the steppes of Moab near the Jordan River. The encounter with Moab is different from the preceding ones: it is much longer, spanning three chapters (Num. 22-24); the Israelites do not

9 The Edomite account, in which Moses has removed himself from the petition, establishes a pattern for the narration in the following episodes inasmuch as Israel as a collective body is the subject of the latter. (Notice how Israel becomes the subject of the narrative already in 20:19.) Whether this synchronic impression corresponds to the diachronic development is another matter.

Io The addition of 2I:26-30 defends Israel's occupation of these territories from any accusation that it was occupying the Moabites' land. The narrator cites what appears to be an ancient and familiar poem (cf. the lament in Jer. 48 ) to demonstrate that the king of Moab had forfeited these lands to the Amorites (from Heshbon), with whom Israel engaged in battle.

II The paragraph is widely thought to represent a late insertion based upon the account in Deuteronomy 3; see the treatment of this passage in Germany, Exodus-Conquest Narrative, 24I-276, as well as Ludwig Schmidt, "Sihon und Og in Num 2I,2Iff." und Dtn 2,24ff.": Ein Beitrag zur Entstehung des Buches Numeri” in Christian Frevel, Thomas Pola, and Aaron Schart (eds.), Torah and the Book of Numbers (Tübingen: Mohr Siebeck, 20I3), 3I4-333. 
directly petition the Moabites for permission to pass through their territories; and there is no military confrontation.

Having witnessed all that the Israelites had done to the Amorites, and fearing that Israel's large numbers would "surely lick clean all that is about us as an ox licks up the grass of the field," the Moabites form a military coalition with the Midianites. Yet instead of coming out to attack the Israelites, the Moabite king, Balak, hires a soothsayer or seer named Balaam to perform rituals of execration and pronounce imprecations on them.

His plans prove futile. Yhwh sends Balaam with messages of reproach for Balak along with awe-inspiring descriptions of Yhwh and his people. Thanks to the deity's strength, Israel is a fierce lion who feasts upon its prey and a wild ox who devours enemy nations. When the infuriated Balak commands Balaam to try again, the seer's words only grow more eloquent:

Word of Balaam son of Beor,

Word of the man whose eye is true,

Word of him who hears El's speech,

Who beholds visions from Shaddai,

Prostrate,

But with eyes unveiled:

How fair are your tents, O Jacob,

Your dwellings, O Israel!

Like palm-groves that stretch out,

Like gardens beside a river,

Like aloes planted by Yhwh,

Like cedars beside the water;

Their boughs drip with moisture,

Their roots have abundant water.

Their king shall rise above Agag,

Their kingdom shall be exalted.

El who freed them from Egypt

Is for them like the horns of the wild ox.

They shall devour enemy nations,

Crush their bones,

And smash their arrows.

They crouch,

They lie down like a lion,

Like the king of beasts;

Who dare rouse them? 
Blessed are they who bless you,

Accursed they who curse you!

Num. 24:3-9, JPS ${ }^{\mathrm{I2}}$

Upon hearing the awe-inspiring description of his enemy, Balak sends Balaam away. As he leaves, he finally delivers the commissioned imprecations; however, he pronounces them not on the Israelites but on the Moabites and other peoples. ${ }^{\text {I3 }}$

All the texts just surveyed likely represent supplements to an older, simpler itinerary that traces Israel's journey from Egypt to Canaan (see the discussion in Part II). Like the battle monuments and war memorials that dot national landscapes, biblical scribes implanted these commemorative accounts across the span of their national narrative. Yet what prompted them to do so? To answer this question, we need to consider a number of other texts.

\section{MOSES'S CONFLICTING MEMORY}

Numbers constructs memories of the nation's first encounters with its neighbors, and in Deuteronomy we can witness how later generations of scribes contested them with counter-memories. ${ }^{14}$ This new account presents Moses, on the eve of both the invasion and his own death, delivering a series of prebattle addresses to the nation. In his first address, the departing leader recounts Israel's history from Sinai (Horeb) to the present, referring extensively to the events depicted in Numbers. His overarching purpose is to demonstrate that the Israelites had enjoyed Yhwh's direct assistance up to this point and therefore had no reason to be anxious about their future as they prepared, in his absence, to cross the Jordan and invade Canaan.

${ }^{12}$ JPS refers to the New Jewish Publication Society of America version of the Tanakh (Hebrew Bible), published in 1985.

${ }^{13}$ On the place of Balaam in the wider narrative(s), see Jonathan M. Robker, "The Balaam Narrative in the Pentateuch/Hexateuch/Enneateuch,” in Frevel, Pola, and Schart, Torah, $334-366$.

${ }^{14}$ Admittedly, this statement needs to be nuanced inasmuch as at least one of the memories in Numbers (the episode with Og in 21:33-35) may presuppose the corresponding account in Deuteronomy. See Jan Gertz, "Kompositorische Funktion und literarhistorischer Ort von Deuteronomium I-3" in Markus Witte et al., Die deuteronomistischen Geschichtswerke in den Büchern Genesis bis 2. Könige: Neue religions- und redaktionsgeschichtliche Perspektiven zur jüngsten "Deuteronomismus"-Diskussion (Berlin: De Gruyter, 2006), I03-I23. 
As Moses pursues his agenda, his recollection of these events differs, often substantially, from the depiction in Numbers. Whereas the latter presents Israel politely petitioning various peoples for permission to pass through their country, in Deuteronomy Moses claims that Yhwh had actually commanded him to harass and "provoke" ( $g-r-h$, Hitpael) some of these peoples so that they would engage in battle! In introducing this startling new information, Moses reports that he had nevertheless requested permits of passage, as if he was uneasy with Yhwh's orders. In fact, his rendition of the petitions makes them sound even more polite and peaceable. The reason why they refused Israel passage, he explains to his audience, is that Yhwh had hardened their hearts. Hence, instead of responding hospitably toward Israel, they came out and fought them, only to suffer devastating defeat.

Moses begins his account of these events by describing how the Israelites, when traveling through the Transjordan, had circumvented the Edomites' territory as long as they could. When describing this encounter, he avoids the name "Edomites," as if it would evoke negative associations; instead, he refers to them as "the descendants of Esau who live in Seir" and "our brothers/kin." He also recalls how Yhwh instructed him to avoid anything that might incite their aggression:

Then Yhwh said to me: "You have been skirting this hill country long enough. Now turn northwards, and instruct the people as follows: 'You will be passing through the territory of your brothers, the descendants of Esau, who live in Seir. Though they will be afraid of you, be very careful not to provoke them. For I will not give you of their land so much as a foot can tread on; I have given the hill country of Seir as a possession to Esau. Any food you eat you shall obtain from them with payment of silver; even the water you drink you shall procure from them with silver." Deut. 2:2-6 (emphasis added)

In describing how Yhwh eventually instructed the nation to cross Edom's borders, Moses has nothing to say about a petition for passage or about how the Edomites attacked them, as depicted in Numbers. The impression he leaves is that Israel actually did pass through this country and that the Edomites, "our brothers" (Deut. 2:8), would have provided food and water for them gratis if Israel hadn't insisted on paying for it. ${ }^{15}$ The contrast to the account in Numbers couldn't be starker.

${ }^{15}$ Pace Jeffrey H. Tigay (The JPS Torah Commentary: Deuteronomy [New York: Jewish Publication Society, I996], 25), the statement in Deuteronomy 2:7 may be an attempt to explain not how the Israelites could purchase provisions but why they had to do so if Israel "had lacked nothing" (i.e., received manna from heaven). 
What follows this episode in Moses's memory are the encounters with the Ammonites and Moabites. As in the case of the Edomites, Yhwh commands Israel not to do anything that would "provoke" a military conflict (Deut. 2:8-23). These instructions take a dramatic turn as the nation approaches the kingdom of Sihon. Moses claims that Yhwh had determined to give Sihon's territory to Israel and had enjoined him to "begin the conquest" by "provoking" this king to wage war with Israel (Deut. 2:24-25).

The way in which Moses fulfills these orders is to do nothing other than send messengers requesting a permit of passage. ${ }^{16}$ The words of the petition embellish the version in Numbers; for example, the messengers insist that they would pay for food and water. Moreover, in an attempt to persuade Sihon to grant Israel safe conduct through his territory, Moses appeals to the precedent set by the Edomites and Moabites:

Let me pass through your country. I will keep strictly to the highway, turning off neither to the right nor to the left. What food I eat you will supply for silver, and what water I drink you will furnish for silver; just let me pass through - as the descendants of Esau who dwell in Seir did for me, and the Moabites who dwell in $\mathrm{Ar}$ - that I may cross the Jordan into the land that Yhwh our god is giving us. Deut. 2:28-29

Here, Moses states explicitly that the Edomites, along with the Moabites, granted Israel license to pass through their borders. ${ }^{17}$

Over the centuries, readers have attempted to harmonize these contradictory accounts. The Samaritan Pentateuch inserted lines from the Numbers account right before Deuteronomy 2:8 so that the Edomite king threatens to assault Israel with the sword; as a result, the verse has to be understood as reporting that Israel passed around Edomite territory instead of crossing through it. ${ }^{{ }^{8}}$ Medieval Jewish interpreters likewise

${ }^{16}$ Notice the way in which the scribes have integrated the new into the old: First, Yhwh commands Moses to begin to take possession of Sihon's land (2:24-25). This is followed by an (embellished) account of the petition to Sihon (2:26-29). Sihon's refusal is then explained by Yhwh to be a part of his larger plan to dispossess him of his territory: "See, I have begun to deliver Sihon and his land to you. Begin and occupy! Take possession of his land!" (2:30-3I). Thereafter, the events in Numbers are recounted: Sihon comes out and attacks Israel, only to forfeit his territory to them (2:32-37).

17 According to Deuteronomy 2:37, Israel also did not encroach upon Ammonite territory.

18 The formulation of Deuteronomy 2:8 already represents a problem inasmuch as it seems to suggest that Israel did not, in fact, pass through Edom's borders. The interpretation of this verse is complicated by the possibility that the entire Edomite pericope in verses 4-7 was added at a later point. The text of the Samaritan Pentateuch is available online; for the relevant passage, go to: www.stepbible.org/?q=version=SP|reference=Deu. 2 . 
attempted to demonstrate that the accounts are not conflicting. For example, the Iberian scholar Ibn Ezra (I089-ca.II67), noticing that Deuteronomy 2 avoids the name "Edom," argued that the "descendants of Esau" permitted Israel passage, while "the king of Edom," who controlled the "King's Highway" (Num. 20:17), displayed belligerence. Critical scholarship, especially that of earlier generations, has often explained the contradictions by assigning these contradictory accounts to two separate source documents, each of which has a distinctive understanding of Israel's history. ${ }^{19}$

What all these approaches fail to appreciate is how the divergent accounts bear witness to a vigorous scribal contest of memory and countermemory, in a manner characteristic of the polyphonic war commemoration that we will be exploring throughout this study. As we shall see, the dispute over Israel's passage through Edom would have had direct ramifications for the ancient readers' stance toward a southern neighbor that came to occupy vast stretches of ancestral Judean lands after Judah fell to the Babylonians in $587 \mathrm{BCE}$.

Admittedly, the omission of any reference to the Edomites' animosity makes good sense given the rhetorical purposes of Moses's address in Deuteronomy: Israel should not be anxious about the impending campaign in Canaan, because their presence intimidates their enemies. Moses describes the encounter with the Edomites to prove his point, suggesting that this people feared Israel and hence did not come out against them. However, this rhetorical purpose does not explain why Yhwh instructs Israel to provoke war with some peoples and to avoid conflict with others. Nor does it account for the different image of the Edomites in Deuteronomy: while Numbers polemicizes against the Edomites, Deuteronomy argues in their favor.

\section{COMMEMORATION AND LEGISLATION}

The authors of Deuteronomy embedded a lengthy law code (chaps. I2-26) in Moses's prebattle addresses, and a section of this code bears directly on our interest in war commemoration:

19 See the discussion of scholarship in David A. Glatt-Gilad, "The Re-Interpretation of the Edomite-Israelite Encounter in Deuteronomy II," Vetus Testamentum, 47 (I997), 44I-455; Wolfgang Oswald, "Die Revision des Edombildes in Numeri xx I4-2I," Vetus Testamentum, 50 (2000), 2I8-232; J. Maxwell Miller, "The Israelite Journey Through (Around?) Moab and Moabite Toponymy," Journal of Biblical Literature, I08 (1989), 577-595. 
No Ammonite or Moabite shall be admitted into the Congregation of Yhwh. None of their descendants, even in the tenth generation, shall ever be admitted into the Congregation of Yhwh. Since they did not meet you on the road with food and water during your journey from Egypt,

and since they hired Balaam son of Beor, from Pethor of Aram-naharaim, to curse you, [But Yhwh your god refused to listen to Balaam. Yhwh your god turned the curse into a blessing for you. For Yhwh your god loves you.] you shall not seek their welfare or prosperity as long as you live.

You shall not abhor an Edomite, for he is your kin. You shall not abhor an Egyptian, for you were a stranger in his land. Children born to them of the third generation may be admitted into the Congregation of Yhwh. Deut. 23:4-9

The lines cited here are an excerpt from a section of rules regulating membership in the "Congregation [qâhâl] of Yhwh." The rules are consistent with the positive attitude toward the Edomites in Moses's prebattle address, while assuming that at least some would be inclined to "abhor" them. In proscribing contempt for this people and permitting membership to their third-generation descendants, Deuteronomy appeals here to a fraternal ethic without saying anything about Israel being granted passage through their territory or provisioned in transit.

This omission is all the more noteworthy since the preceding lines refer precisely to these expectations of hospitality as the reason for excluding Ammonites and Moabites from the Congregation of Yhwh. The book of Numbers has nothing to say about these two peoples denying Israel rights to cross their territory. Likewise, in Deuteronomy 2 Moses recalls that the Israelites went out of their way to skirt its borders and were ordered by Yhwh not to provoke a conflict with them. ${ }^{2 \mathrm{I}}$

While the qâhâl regulations in Deuteronomy 23 most likely did not originate in complete isolation from the narrative in Numbers, it's difficult to discern a clear sequence of composition. ${ }^{22}$ Read against the backdrop of the laws in Deuteronomy 23, the episode in Numbers suggests that the Edomites not only failed to provision their kin with bread and water, even when Israel promised to pay for it; they also waged war against them. The

20 The indented and italicized section, which adds a new reason along with three tangential remarks, was likely added by a later hand, as scholars have postulated over the years; see the discussion in Eckart Otto, Deuteronomium I2-34 (Freiburg: Herder, 2016), as well as Markus Zehnder "Anstösse aus Dtn 23,2-9 zur Frage nach dem Umgang mit Fremden," Freiburger Zeitschrift für Philosophie und Theologie, 52 (2005), 300-3 I 4.

${ }^{2 I}$ In Deuteronomy 2, Moses has nothing to say about the incident with Balaam.

${ }^{22}$ While the Edom account in Numbers seems to be older, it may have been expanded with elements from similar texts and in reaction to views set forth not only in Deuteronomy but also in Genesis (discussed in Chapter 2). 
reader should draw a conclusion: if the Ammonites and Moabites are to be banned from the qâhâl for an infraction of hospitality, the nation should rethink its fraternal stance toward the Edomites, who were not only inhospitable but outright hostile. This polemical posture directly undermines Deuteronomy's explicit injunction: "Do not abhor the Edomite, for he is your kin." 23

A late addition to the book of Ezra-Nehemiah reveals how some circles in the postexilic period applied Deuteronomy 23 to issues of their time:

At that time the Book of Moses was read for the hearing of the people. It was found written that no Ammonite or Moabite should ever enter the Congregation [qâhâl] of God because they did not meet Israel with bread and water, and because they hired Balaam against them to curse them (but our god turned the curse into a blessing). When they heard this teaching, they separated all the mixed multitude from Israel. Neh. I $3:$ I -3

This paragraph has been prefaced to Nehemiah's memoirs, which describe the measures he took as governor to safeguard Judah from deleterious alliances with its neighbor, such as intermarriage with Ammonites and Moabites (Neh. I3:23, see also I3:28). The first thing Nehemiah recounts is how he forced Tobiah, a Transjordanian leader identified several times as an Ammonite, to relinquish his property within the precincts of Jerusalem's temple. Against the backdrop of the paragraph cited above, Tobiah's expulsion is to be understood not as a conflict between two personalities on Judah's political stage but as one piece of a larger reform undertaken by the entire community after studying "the Book of Moses" and learning about the Ammonites' and Moabites' inhospitable conduct at a crucial moment in the nation's history. ${ }^{24}$

\section{DAVID IN THE WILDERNESS}

To challenge clear-cut rulings such as those in Deuteronomy 23, one had to creatively fabricate more favorable memories of Israel's neighbors. An example of this memory-making is found in the book of Samuel. When the insurgent Absalom seizes his father's throne, he forces David and his

23 Juan Manuel Tebes, "'You Shall Not Abhor an Edomite, for He Is Your Brother': The Tradition of Esau and the Edomite Genealogies from an Anthropological Perspective" in Ehud Ben Zvi (ed.), Perspectives on Hebrew Scriptures III (Piscataway: Gorgias, 2008), I75-2I 6 .

${ }^{24}$ See Jacob L. Wright, Rebuilding Identity: The Nehemiah Memoir and Its Earliest Readers (Berlin: De Gruyter, 2003), 3 I 5-3 I9. We will revisit this important episode with Tobiah in Part II. 
supporters to evacuate the capital and seek refuge in the Transjordan. Famished and fatigued, they are eventually met by a delegation of three Transjordanian dignitaries, one of whom is an Ammonite prince. The delegation brings the refugees not just bread and water (as in Deut. 23:4-9; Neh. I3:I-3) but also an extraordinary assortment of fine viands (wheat, barley, meal, parched grain, beans, lentils, honey and curds, lamb, and cheese) along with precious gifts (2 Sam. 17:27-29). The depiction of these exiles as "famished" and "fatigued," trekking through the "wilderness," brings to mind the Pentateuchal passages we just surveyed. Thus, Moses commands Israel to blot out the memory of the Amalekites - the landless marauders who attacked the nation right after the exodus because they "surprised you on the march, when you were famished and fatigued, and cut down all the stragglers in your rear" (Deut. 25:18, emphasis added).

The parallels in language, scenario, and commemorative function are obvious. By appealing to a competing memory of hospitality, one related to the greatest figure in Judah's history during his trials and tribulations, scribes could make a case for a more inclusive policy toward neighboring populations: Perhaps the Ammonites, along with the Moabites, had failed to provide bread and water to the nation as it passed its borders, but when Judah's beloved king and his followers were wandering in the wilderness, it was the leaders of Transjordanian kingdoms who brought them not only bread and water but all manner of costly comestibles. ${ }^{25}$

In my books on King David, I compare this episode to the many memories of representative individuals and groups providing succor to David and his men during his rise to power and then later when he is exiled from Jerusalem. The narrative of David's wilderness wanderings has much in common with the account of the exodus conquest (e.g., the itinerary framework). While one relates to a pivotal period in the formation of the nation, the other relates to a pivotal period in the formation of the state. Their sequence in the national narrative reflects the primacy that the biblical narrative attaches to the people rather than the palace.

In one of the most dramatic episodes in David's rise to power, Nabal the Calebite refuses to provide succor to David and his troops: "Should I take my bread and water, and the meat I have slaughtered for my shearers, and give it to men coming from who knows where?" (I Sam.

${ }^{25}$ A memory of Moabite hospitality in the book of Samuel (I Sam. 2I:3-4) tells how "the king of Moab" granted asylum to David's parents during the time when he was being hounded by Saul. 
25:II). As David mounts an attack on Nabal's house, his wife Abigail saves the day by sending a generous supply of assorted foods to the warlord and his men: two hundred loaves of bread, two pithoi of wine, five dressed sheep, five seahs of parched corn, a hundred raisin cakes, and two hundred cakes of pressed figs. Like the actions of Jacob when he confronts Esau and his troops (discussed in Chapter 2), Abigail sends the donkeys bearing these gifts before her arrival. When she intercepts David on the warpath, she utters an eloquent speech (longer than that of any woman in the biblical narratives), in which she calls her husband a "wretched fellow" and mocks his name.

In Part IV, we will explore the similar account of Jael, who directly defies her Kenite husband's politics. She does so, however, not by feeding a future king but by assassinating a Canaanite general, who, under the rule of the king of Hazor, attacks Israel right before it attempts to establish the first king of its own.

\section{WAR MEMORIES AS CASUS BELLI}

The scribes who invented memories of the nation's earliest encounters with neighboring peoples understood that these memories had direct implications for a whole host of political issues. Thus, they could influence the postexilic community's posture toward individuals in their midst, as we saw in Nehemiah's account. Or they could have an impact on larger territorial disputes, and even provide the casus belli for a military confrontation, as we will see now in two texts.

In the account of Jephthah from the book of Judges, the memories and counter-memories found in the books of Numbers and Deuteronomy play a key role in prebattle negotiations with the Ammonites. As they prepare for war, Jephthah and the Ammonite king argue at length about the course of events leading up to their conflict. Jephthah demands an explanation for the Ammonites' bellicosity, and in response, the foreign ruler claims that Israel, on its way from Canaan to Egypt, seized a large portion of their territory - "from the Arnon to the Jabbok and the Jordan." Jephthah contests the claim with a detailed review of those events in Israel's early history:

Israel did not take away the land of Moab or the land of the Ammonites, but when they came up from Egypt, Israel went through the wilderness to the Red Sea and came to Kadesh. Israel then sent messengers to the king of Edom, saying, "Let us pass through your land." But the king of Edom would not listen. They also sent to the king of Moab, but he would not consent. So Israel remained at Kadesh. Then 
they journeyed through the wilderness, went around the land of Edom and the land of Moab, arrived on the east side of the land of Moab, and camped on the other side of the Arnon. They did not enter the territory of Moab, for the Arnon was the boundary of Moab. Israel then sent messengers to King Sihon of the Amorites, king of Heshbon, and Israel said to him, "Let us pass through your land to our country." But Sihon did not trust Israel to pass through his territory. He gathered all his people together, encamped at Jahaz, and fought with Israel. Then Yhwh, the god of Israel, gave Sihon and all his people into the hand of Israel, and they defeated them. So Israel occupied all the land of the Amorites who inhabited that country. They occupied all the territory of the Amorites from the Arnon to the Jabbok and from the wilderness to the Jordan. So now Yhwh, the god of Israel, has conquered the Amorites for the benefit of his people Israel. Do you intend to take their place? Judg. II:I 5-23

Jephthah is the son of a harlot and, after being banished from his home, becomes a warlord with a band of marauders. Later, when the Ammonites attack Gilead, he is summoned back to his place of origin, and there he manages to rise to the highest seat of authority. What's remarkable about his story is that its authors depict him as a social outcast and bandit who not only displays firsthand knowledge of Israel's written history but also synthesizes competing perspectives in these texts with the expertise of an experienced scribe.

Jephthah's understanding of his people's history follows the contours of the account in Numbers while integrating aspects of the (revisionist) view articulated by Moses in his own eve-of-battle address in Deuteronomy. ${ }^{26}$ The warlord modifies the Numbers narrative on certain points (e.g., he adds a petition for passage sent to, and rejected by, "the Moabite king"). He also fleshes out the underlying rationale as he makes a case against the Ammonites. For example, Numbers cites older poetic sources to prove that Israel took possession only of Amorite lands and did not (directly) expropriate Moabite territories (Num. 2I:I4-I 5, 26-30). Although Jephthah's response to the Ammonite king confuses the Ammonites with the Moabites in several respects (e.g., he identifies Chemosh as the national deity of the Ammonites rather than the Moabites), he makes sophisticated use of the Numbers narrative to argue that Israel, during the days of the exodus, had not traversed the Ammonite country and had conquered only territories belonging to the Amorites. On this point, Jephthah reinforces the position that Moses sets

${ }^{26}$ In Deuteronomy 2:IO-I 2, 20-23, a redactional layer can be isolated that tells how Yhwh had actually fought on behalf of the Edomites, Moabites, and Ammonites in order to give them their lands, as he was about to do with respect to Israel. 
forth in his speech in Deuteronomy - namely, that the nation had circumvented the Ammonites (Deut. 2:37). ${ }^{27}$

The exchange with the Ammonite king sheds light on the larger political issues (with the Moabites!) that informed the composition of the conquest accounts in Numbers. The authors of the Jephthah account were less interested in justifications for war than matters related to the borders of Israelite possessions in the Gilead. Their debate on the legitimacy of Israel's claims to conquered lands continues long after the downfall of the kingdoms of Israel and Judah: the rabbis argued, in keeping with the apologetic thrust of the biblical texts, that (portions of) Ammonite and Moabite territory could be conquered by the generation of the exodus because the Amorite ruler Sihon had already wrested it from these neighbors (b. Gittin 38a).

Another example of memories serving as a casus belli is found in the book of Samuel, where the prophet approaches King Saul and declares to him Yhwh's instructions:

I am the one whom Yhwh sent to anoint you over his people Israel; now listen to the words of Yhwh: "Thus says Yhwh of the Hosts - I will punish Amalek for what they did in opposing Israel when they were on the road coming up out of Egypt. Now go and smite Amalek, and utterly destroy all that they have. Do not have pity on them. Kill both man and woman, child and infant, ox and sheep, camel and donkey." I Sam. I 5:I-3

The account of Saul's war against the Amalekites illustrates Deuteronomy's injunctions to "remember what Amalek did to you on the road from Egypt" and to be sure "to not forget to blot out the memory of Amalek from under heaven" (Deut. 25:I7-I9; see also Exod. I7:I4, I6). The account goes on to present Saul warning the Kenites, who live among the Amalekites, to remove themselves from the line of fire. The king grants special protection to this people because they, in contrast to the Amalekites, had showed hospitality (hesed) to the Israelites when they were coming out

${ }^{27}$ From a diachronic perspective, Jephthah's reading of the Numbers narrative may anticipate the view that has been subsequently ascribed to the more authoritative figure of Moses in Deuteronomy 2. On the relationship of Jephthah's account to passages from the Pentateuch, see the synchronic analysis by Dieter Böhler, Jiftach und die Tora: Eine intertextuelle Auslegung von Ri I0,6-I2,7 (Frankfurt: Peter Lang, 2008), as well as the diachronic analysis by Germany, Exodus-Conquest Narrative, 244-276. That the account reflects a postexilic Judean land claim in the Transjordan is suggested in Friedrich-Emanuel Focken, Zwischen Landnahme und Königtum: Literarkritische und redaktionsgeschichtliche Untersuchungen zum Anfang und Ende der deuteronomistischen Richtererzählungen (Göttingen: Vandenhoeck \& Ruprecht, 20I4). 
of Egypt. In Part IV, we will revisit this text and attempt to discern what its authors may have been referring to.

Thus, just as the denial of passage could precipitate military aggression, the contested memories and commemoration of these events could serve as a casus belli. Throughout history, states have justified their decisions to go to war by appealing to memories of prior, unwarranted aggression. Many kingdoms of the ancient Near East stored detailed documentation concerning relations with competing powers, and even if these records related to events from centuries before, they came in handy when rulers sought a (legitimate) reason for declaring war or establishing an alliance. ${ }^{28}$

Notably, the biblical memories of Israel's relations with other peoples continued to exert their political and didactic force long after the demise of its kingdoms. The reason for this is that, as we shall see throughout our study, the architects of these memories have consciously crafted them for the needs of a larger audience than the rulers of states.

\section{PERMITS OF PASSAGE IN AN AGE OF EMPIRES}

During the most formative period in the Bible's history, the practice of independent armies requesting passage through the territories of third parties was already long passé. In the final years of their existence, the kingdoms of Israel and Judah were vassals to suzerain powers in Mesopotamia and Egypt. As in the case of the Duke of MecklenburgSchwerin with which we began this chapter, kings from the ancient Near East required their vassals, by means of verbal oaths and written treaties, not only to allow troops to traverse their territories but also to provision them with food and supply their own soldiers to serve on the campaign. Failure to do so was promptly punished, as was any effort to aid and abet enemy forces by permitting them to cross one's borders - the crime committed by the Duke.

As these imperial powers evolved and subjugated surrounding kingdoms, they created an administrative system consisting of satrapies and provinces whose governors they directly appointed. In his memoirs from the fifth century BCE, the Judean governor Nehemiah tells how he and his retinue made their way from the Persian court to the province of Judah,

${ }^{28}$ A superb case study, from the perspective of Hittite scribal activities, is provided in Itamar Singer, The Calm Before the Storm (Atlanta: Society of Biblical Literature, 20II), 73 I-766. 
not only with imperial cavalry and soldiers but also with royal letters (a "passport" or "orders of safe conduct") that charged other provincial governors to grant him passage until he arrived in his homeland (Neh. 2:7-9). From both Greco-Roman sources and recently discovered cuneiform documents from Mesopotamia, we know much about the network of roads connecting all points of the expansive Persian Empire (with stations and depots strategically located along the routes), and we've even recovered some of the actual authorizations and receipts for the food provisions that were paid to the armies and emissaries who traveled these routes. ${ }^{29}$

Such were the conditions of the Pax Persica, which stand in direct continuity with the administrative innovations introduced by Assyria (the Pax Assyriaca) and which continued to the days of the Roman emperors (the Pax Romana). It was in this age of empires that our biblical texts were being composed. The geopolitical structure instituted by these superpowers was, however, ill-suited to the biblical project of war commemoration, which explains why our scribes invested their imagination in a world of petty states that jockeyed for control long before imperial powers (re-)emerged to make their influence felt across the southern Levant.

29 A selection of the relevant materials is reproduced in Amélie Kuhrt, The Persian Empire: A Corpus of Sources from the Achaemenid Period (New York: Routledge, 2007), pt. 4. For comparative perspectives on travel in the ancient Near East, see Rocío Da Riva, Martin Lang, and Sebastian Fink (eds.), Literary Change in Mesopotamia and Beyond and Routes and Travelers Between East and West: Proceedings of the 2nd and 3 rd Melammu Workshop (Münster: Zaphon, 20I9). 